\title{
Editorial
}

\section{COVID-19 Transformaciones a nivel globalizado en educación}

\section{COVID-19 Transformations at the globalized level in education}

\author{
Cleofé Genoveva Alvites-Huamaní ${ }^{1}$ \\ https://orcid.org/0000-0001-6328-6470 \\ Universidad Alas Peruanas, Perú
}

\section{Cita Recomendada}

Alvites-Huamaní, C. (2020). COVID-19 Transformaciones a nivel globalizado en educación. Hamut'ay, 7(2), 5-7.

http://dx.doi.org/10.21503/hamu.v7i2.2147

\section{INTRODUCCIÓN}

Como cada año las instituciones educativas de educación básica y universitaria a nivel nacional iniciaban su año académico en el mes de marzo del 2020, sin presagiar que destino se avizoraba y lo insólito que iba a suceder en menos de 15 de iniciado este mes, pues la magnitud del impacto del COVID-19 ha mermado en los sistemas educativos a nivel mundial, se han cerrado escuelas, ya no va más los espacios físicos, toda la infraestructura y equipamiento que se tenía han pasado a un segundo plano, porque se pasó de un sistema de educación presencial a una educación virtual, a distancia o remota García-García, (2020), teniendo la omnipotencia las tecnologías de la información y comunicación (TIC), la aula de clase está en el ciberespacio, en la nube. Los cambios abismales que se han realizado a nivel educativo han sido vertiginosos en todo el mundo, pues la pandemia del COVID-19 trajo consigo desafíos gubernamentales, políticos, laborales, científicos y la educación no ha estado exenta (Castañeda-Hernández \& Rodríguez-López, 2020). Cambios que han generado una mirada diferente a las tecnologías y a la

\section{INTRODUCTION}

As every year the educational institutions of $\mathrm{Ba}$ sic and university education at international level began their school year in March 2020, without predict that fate is in sight and unusual that was going to happen in less 15 was initiated this month, so the magnitude of impact of COVID-19 has reduced education systems globally, has closed no longer go beyond the schools physical spaces, all infrastructure and equipment have now taken second place, because moved from education on site system to remote education, to distance or remote education García-García, (2020), taking omnipotence the information and communication technologies, the classroom is in cyberspace, cloud based. The abysmal changes that have been carried out an educational level has been enormous around the world, so the COVID-19 pandemic brought unprecedent government, political, labor, scientific challenges and the education has not been exempt (Castañeda-Hernández \& Rodríguez-López, 2020). Changes have created through different perspective at technologies and virtually in the area of education, as had never 
virtualidad en el ámbito educativo, como nunca se hubiese pensado antes, aunado a ello las competencias digitales que de manera inmediata debían de adquirir los docentes para adaptarse a esta nueva forma de impartir enseñanza. Para Laro, (2020) refiere que para el desarrollo del ser humano y de la sociedad en el futuro la educación y el sistema educativo es una pieza primordial y que con la aplicación de las tecnologías permitirán mejorar la calidad de la enseñanza y son los docentes encargados de hacer realidad esta simbiosis.

\section{Educación en tiempos de pandemia}

Cuando se declara la pandemia del COVID-19 a nivel mundial, muchas de las instituciones educativas a nivel básica y universitaria se cierran en 180 países y el $85 \%$ de los estudiantes en todo el mundo dejaron de asistir a sus centros de estudios, (Rogers \& Sabarwal, 2020). A pesar que no se vislumbraba un panorama alentador para la educación, muchos de los países actuaron de inmediato, se implementaron una serie de medidas para que en esta situación problemática del confinamiento la educación continuará, lo que conllevo a que se virtualizará y se brindará una enseñanza a distancia, para lo cual los medios tecnológicos han sido un soporte para servir de medio y permitir que los estudiantes retornen a sus actividades académicas y como lo refiere Chiecher \& Melgar (2018) la innovación educativa con TIC ayudan a romper las barreras de espacio y tiempo al brindar procesos formativos abiertos, flexibles y con acceso rápido a la información (Porlán, 2020). Al generarse este cambio, también se implementaron nuevas metodologías, pues el centro del proceso enseñanza aprendizaje ya no era el docente, sino el estudiante, más autónomo en su aprendizaje al tener a su alcance toda la información e infraestructura tecnológica de manera sincrónica y asincrónica, (Moreno-Correa, 2020). Las instituciones educativas se vieron obligadas a implementar en sus aulas virtuales recursos y herramientas tecnológicas que estuvieran al alcance de los estudiantes las 24 horas del día.

\section{Transformaciones educativas con tecnologías en COVID-19}

La propagación del COVID-19 hizo que la educación básica y universitaria se adapte a metodologías thought of it before, in addition digital competences in immediately the teachers had to acquire to adapt to these new modes of educational delivery. According Laro, (2020) refers to human and social development in the future education and education system is a primary piece with application of the technologies will improve the quality of state education and teachers are faced to implement this symbiosis.

\section{Education time of pandemic}

When COVID-19 pandemic was declared globally, many educational institutions at level basic and university are closed in 180 countries and 85\% students of different nationalities failed to attend to their study centers (Rogers \& Sabarwal, 2020). Even though no prospect an scene encouraging for education, many countries acted promptly, A series of measures were taken for this problematic situation of confinement, education will continue, which bring to will be virtualizing and provide a distance learning, for which technical resources have been a support to offer a means and allow students return to their academic activities as referred Chiecher \& Melgar (2018) Educational Innovation with TIC help break the barriers of time and space while providing open, flexible formative processes and faster Access to information (Porlán, 2020). When change is generated, also began to implemented new methodologies because the center of teaching and learning process was no longer the teachers but the student, being more autonomous in his learning and has Access all the information and technological infrastructure in a synchronous and asynchronous way (Moreno-Correa, 2020), since educational institutions were forced to implement virtual classrooms resources and technological tools were accessible 24 hours a day.

\section{Educational transformations with technologies COVID-19}

By the spread of COVID-19 to basic education and university have had to adapt hybrid methodologies where virtually has greater emphasis and the application of technologies has been fundamental overcoming space barriers before were essential in this relationship student-teacher int the teaching-learning process. 
hibridas donde la virtualidad tiene un énfasis mayor y la aplicación de las tecnologías ha sido fundamental para vencer esas barreras de espacio, que antes eran fundamentales en esa relación estudiante-docente en el proceso de enseñanza aprendizaje.

El COVID-19 ha hecho repensar a la educación, ya que ha permitido ver que las tecnologías son una oportunidad, ya que proporcionan herramientas y recursos digitales gratuitos y de acceso abierto, no importando el nivel de estudios, aspectos socioeconómicos, etnia, religión u otro tipo de barreras que de manera presencial se presentaban, (D'Orville, 2020). Pero no solo las metodologías han sido las que han tenido una transformación considerable, sino también el rol de los estudiantes, docentes y padres de familia, debido a que las aulas se transfirieron a sus hogares y la enseñanza se imparte en un espacio acondicionado para ello.

Siempre que se presente una adversidad debe mirarse el lado positivo y en estos tiempos las tecnologías han sido un aliado, aunque algunos refieran que puede generar una mayor brecha digital, Paladines (2020) que puede suceder o no, pero por el momento se debe centrar en las posibilidades de continuar educando a estas nuevas generaciones. $\mathrm{El}$ Internet ahora tiene un mayor acceso y las herramientas digitales pueden facilitar al docente nuevos tipos de experiencias de enseńanza-aprendizaje, en las aulas virtuales se puede realizar intercambio con estudiantes de diferentes países o regiones, aprender de su historia, cultura o realizar trabajo colaborativo o dar sus opiniones de una lectura compartida en un foro, videoconferencia u otro tipo de producto digital, (Carpenter, Trust \& Green, 2020). Y los estudiantes tienen la oportunidad de aprender de una manera más interactiva, desarrollar otras habilidades y destrezas, a través del uso de nuevas narraciones utilizando las tecnologías, al tener a su alcance libros digitales interactivos con realidad virtual y aumentada que permiten una situación realista de los contenidos que se presentan entre otros muchos recursos digitales, (Jadán-Guerrero et al., 2020), ya que la virtualidad y las tecnologías permiten al estudiante tener al alcance todo un bagaje de información a un solo clic y siendo ellos quienes de manera habitual utilizan las tecnologías, sus recursos y herramientas digitales.
COVID-19 has made education rethink, has also allowed to see technologies are an opportunity, since provide tools and free digital resources and open-access, no matter level of education, socio-economic, ethnicity, religion or other types of barriers that face to face way were presented, (D'Orville, 2020). But it is not methodology alone has been ones and have had considerable transformation, but also the roll of students, parents, due to the classrooms were transferred to their homes and teaching is provided in accommodated space for it.

Always from every adversity, let's just look at the bright side, in today's time the technologies had been positive ally, even if some relate that can generate greater digital divide, where this may be or not happen, but at present, needs to focus the possibilities to continue educating the new generations. Now Internet has greater access to digital tools can make teachers knew types of teaching-learning experiences, virtual classrooms can be done Exchange with students from different countries or regions, learn from its history, culture or do collaborative working or give opinions of a shared reading in a forum, video-conference or other type pf digital product, (Carpenter, Trust $\&$ Green, 2020). Students provide learning opportunity in a way more interactive, develop other abilities and skills, through use of new narrations and technologies, counting on interactive digital books with virtual reality and increased which allows a realistic content situation that presented among other digital resources, (Jadán-Guerrero et al., 2020), as virtuality and technologies allow the student has to reach a whole background information in just one click and they are who, on a regular basis, use the technologies, resources and digital tools. 


\section{REFERENCIAS BibliográficAS}

Castañeda-Hernández, D. \& Rodríguez-López, J. (2020). COVID-19 - La pandemia. Una mirada a sus impactos en Latinoamérica. Revista Venezolana de Gerencia (RVG), 25 (91), 746-753.

Carpenter, J., Trust, T. \& Green, T. (2020). Transformative instruction or old wine in new skins? Exploring how and why educators use HyperDocs. Computers \& Education, 157. https://doi.org/10.1016/j.compedu.2020.103979

Chieche, A.C. \& Melgar, M. (2018). ¿Lo saben todo? Innovaciones educativas orientadas a promover competencias digitales en universitarios. Apertura, 10 (2), 110-123. https:// doi.org/10.32870/Ap.v10n2.1374

D'Orville, H. (2020). COVID-19 Causes unprecedented educational disruption: Is there a road towards a new normal? Prospect. https://doi.org/10.1007/s11125-020-09475-0

Garcia-Garcia, M. (2020) La docencia desde el hogar. Una alternativa necesaria en tiempos del Covid 19. Revista Polo del Conocimiento, 5 (4), 304-324.

https://doi.org/10.23857/pc.v5i3.1318

Jadán-Guerrero, J., Sanchez-Gordon, J., Acosta-Vargas, P., Alvites-Huamaní, C. \& Nunes, I. (2020). Interactive Storytelling books for fostering inclusión of children with special needs. https://doi.org/10.1007/978-3-030-51369-6_30

Laro, E. (2020). Innovar enseñando: La educación del futuro. Las TICS como factor motivador en la enseñanza. REJIE Nueva Época, 21 (1), 11-23

Moreno-Correa, S.M. (2020). La innovación educativa en los tiempos del Coronavirus. Salutem Scientia Spiritus, 6(1), 14-26.

Paladines, K. (2020). Dscurso digital en tiempos de COVID-19. Digitalidad y pandemia. Grupo de investigación Sociedad, psicoanálisis y tecnología digital. Recuperado de https://www.puce.edu.ec/pdf/digitalidad-y-pandemia.pdf

Porlán, R. (2020). El cambio de la enseñanza y el aprendizaje en tiempos de pandemia. Revista de Educación Ambiental y sostenibilidad, 2(1), 1502-1507.

https://doi.org/10.25267/Rev_educ_ambient_sostenibilidad.2020.v2.i1.1502

Rogers, H. \& Sabarwal, S. (2020). COVID-19: Impacto en la educación y respuestas de política pública. Grupo Banco Mundial. 